\title{
Political Allusions in the Decembrist Revolt
}

\author{
M. S. Belousov
}

For citation: Belousov M.S. Political Allusions in the Decembrist Revolt. Vestnik of Saint Petersburg University. History, 2018, vol. 63, issue 2, pp. 345-360. https://doi.org/10.21638/11701/spbu02.2018.202

The article provides an insight into political allusions, i.e. references to the well-known historical events of the Decembrist milieu in the interregnum period. The emergence of a "dictator" was one of the most common allusions. The analysis enables us to debunk the statement that S.P. Trubetskoi was elected dictator. Instead, it can be stated that he was proclaimed one on the initiative of K. F. Ryleev. This appointment did not limit the powers of the latter in any way. Moreover, K. F. Ryleev managed to take advantage of S.P. Trubetskoi's impressive title. Another example of allusion is the assassination of Julius Caesar by Brutus. The usage of Roman tyrant-fighting references was one of the characteristic features of the regicide plot. The setting for the revolt can be also considered symbolic. The article points out that K. F. Ryleev's objective was not to arrest certain senators and force them into issuing a manifest. On the contrary, going out to take a stand on the square was planned as an armed public demonstration (modeled on the Brazil revolution) in front of the building occupied by the state body whose sole function was to make decisions about the further fortune of the dynasty and the political order of Russia. Indeed, it took place on November 27, 1825, when the Senate broke the order of succession to the throne and ignored the will of Alexander I. Apart from these, the allusion to Leon Island (with regard to the plans to retire to Kronstadt in the case of the failure of St. Petersburg revolt) was also used by the conspirators.

Keywords: Decembrists, Decembrist movement, historiography, allusion, dictator, Brutus, Senate square.

\section{Политические аллюзии в восстании декабристов}

\section{М. С. Белоусов}

Для цитирования: Belousov M.S. Political Allusions in the Decembrist Revolt // Вестник Санкт-Петербургского университета. История. 2018. Т. 63. Вып. 2. С. 345-360. https://doi. org/10.21638/11701/spbu02.2018.202

В статье исследуются политические аллюзии на известные исторические события, которые появились в среде декабристов в период междуцарствия. Обзор историографии показывает, что сюжет рассматривался в исторических и филологических исследованиях, но синергии двух наук не получилось. Историки реконструировали полити-

Mikhail S. Belousov - PhD in History, Associate Professor, St. Petersburg State University, 7-9, Universitetskaya nab., St. Petersburg, 199034, Russian Federation; m.belousov@spbu.ru

Михаил Сергеевич Белоусов - канд. ист. наук, доц., Санкт-Петербургский государственный университет, Российская Федерация, 199034, Санкт-Петербург, Университетская наб., 7-9; m.belousov@spbu.ru

This research was supported by the grant of the President of the Russian Federation for the young PhDs no. MK-5578.2018.6 "The movement of the Decembrists: from historiography to historical memory".

(c) Санкт-Петербургский государственный университет, 2018 
ческие биографии своих протагонистов, а филологи изучали литературное влияние и ключевые образы в творчестве. В итоге соединения двух тенденций не произошло. Наиболее известной аллюзией стал образ «диктатора». В статье показано, что в историографии активно обсуждались статус и значения этой должности. Приводимый далее анализ дает возможность отказаться от утверждения, что С.П. Трубецкой был избран диктатором, и перейти к тезису о том, что он был провозглашен диктатором по инициативе К. Ф. Рылеева. Этот шаг никак не ограничивал полномочий последнего, но яркий образ давал возможность использовать имя С.П.Трубецкого для решения собственных задач. Другой пример аллюзии - это апеллирование к истории убийства Цезаря Брутом. Использование римского тираноборческого колорита было одним из приемов в подготовке цареубийства. Определенную символичность можно усмотреть в выборе места восстания. В статье показано, что целью К. Ф. Рылеева являлся не арест конкретных сенаторов и принуждение их к изданию манифеста, наоборот, выход на площадь представлял собой вооруженную манифестацию по образу бразильской революции - перед государственным органом, олицетворявшим полномочия принимать решения о дальнейшей судьбе династии и политических порядков в России, как это и произошло 27 ноября 1825 г., когда решением Сената был нарушен порядок перехода престола и проигнорировано завещание Александра I. Кроме того, затрагивается сюжет использования аллюзии на остров Леон в контексте планов декабристов отступить в Кронштадт в случае провала петербургского восстания.

Ключевые слова: декабристы, движение декабристов, историография, аллюзия, диктатор, Брут, Сенатская площадь.

The revolt on December 14, 1825, is one of the most well-studied but not entirely comprehended events of the Russian history. For a long time it was considered to have been the last coup d'état, but due to a famous American authority on the Decembrist movement it turned into the first Russian revolution ${ }^{1}$. According to M. V. Nechkina, it was the first attempt of the armed attack on the autocracy ${ }^{2}$. In the context of recent studies it can be called an unsuccessful rehearsal of the future discord ${ }^{3}$. A distinctive feature of this crucial moment was the fact that the conspiracy was orchestrated by a romantic poet K. F. Ryleev. At the same time his closest associates A. A. Bestuzhev and V. K. Küchelbecker also played an important role in these events. It is hard to deny that poetical practices were transferred to a political sphere. That is why it does not come as a surprise that numerous political allusions, i.e. references to some well-known political events or works of literature, can be found in the history of interregnum. Their analysis could modify the entrenched views on the events in question.

One would think that this most interesting issue was destined to attract attention and become the foundation of historical and philological research. Many scholarly studies focus on the biographies and works of the poets-Decembrists. We will touch upon the most important of them. V.I. Maslova, having examined the biography and poetry of K. F. Ryleev, notes that such classical authors as Anacreontos, Sappho, Tibullus and Propertius played a crucial role in the development of his literary style $\mathrm{e}^{4}$. Moreover, the tendency to use historical

1 Mazour A. G. First Russian Revolution 1825. The Decembrist Movement. Its Origins, Development and Significance. Stanford, California, 1937.

2 Nechkina M. V. Dvizhenie dekabristov. Vol. I. Moscow, 1955.

3 Dvornichenko A. Yu. Smuta kak faktor rossiiskoi istorii // Vestnik Sankt-Peterburgskogo universiteta. Istoriia. 2018. Vol. 63, iss. 3. (in print)

${ }^{4}$ Maslov V.I. Literaturnaia deiatel'nost' K. F. Ryleeva. Kiev, 1912. P. 134. 
events as elements of a storyline appeared quite early. A. E. Presniakov argues that it is hardly possible to distinguish the Decembrists as a group, and it is better to focus on the characteristics of the generation in general. The historian claims that the "cultural-psychological approach features the image of a romantic-revolutionary as the most expressive and typical of that generation" . K. F. Ryleev, in turn, was the most "expressive" figure of that generation. A. G. Tseitlin tends to study the development of K. F. Ryleev as a poet in the context of his political activities, interpreting his poetry as a creative reflection of the ideas of the Decembrists $^{6}$. However, for justice' sake we should admit that the desired ends were not achieved, the book contains nothing more but a typical analysis of K. F. Ryleev's literary activities.

Almost the same feedback can be given on the work about the life and literary activities of A. A. Bestuzhev by an American philologist L. Leighton ${ }^{7}$. G. Barratt notes that the monograph is clearly structured - the scholar examines the milestones of the poet's biography and the main trends of his literary work, but doesn't come up with any new interpretations of his prose and poetry ${ }^{8}$. E. Shepard mentions that L. Leighton succeeded in featuring a many-sided personality of the poet. However, his assessment of the poet's literary work generally repeats the conclusions of other authors ${ }^{9}$. V. Terras dwells on the part focused on the Decembrist revolt accentuating the author's emphasis on the changes of A. A. Bestuzhev's character and personality with regard to this event ${ }^{10}$. In short, L. Leighton has managed to produce a substantial and well-grounded biography of the poet, but failed to trace the connection between his literary work and politics.

The monograph by P.O'Mara, which actually represents a political biography of K. F. Ryleev, is also worthy of note ${ }^{11}$. Looking into the events of the interregnum, the historian stresses that the preparation for the revolt was an attempt to "turn the bunch of idealists, who had previously been indulged only in writing and talking, into a group, to some extent resembling a military organization"12. Consequently, all the key moments of the secret society's agenda in the period of interregnum are examined by the author in this context. The scholar claims that K.F. Ryleev was a mastermind of the conspiracy, and proclaiming S. P. Trubetskoi a dictator was just an attempt to take advantage of S. P. Trubetskoi's name, while the plan itself had been developed by K. F. Ryleev. It is also mentioned that K. F. Ryleev was not an advocate of the regicide idea. In short, the following conclusion is drawn: a poet-idealist appears to have been a central figure of the conspiracy. L. Leighton in his review commends the monograph, yet, points out that the author has failed to merge the two Ryleevs (Ryleev the poet and Ryleev the politician) into a single entity ${ }^{13}$.

${ }^{5}$ Presniakov A. Motivy real'noi politiki v dvizhenii dekabristov // Bunt dekabristov. Leningrad, 1926. P.33.

6 Tseitlin A. G. Tvorchestvo Ryleeva. Moscow, 1955.

7 Leighton L. G. Alexander Bestuzhev-Marlinsky. Boston, 1975.

8 Barratt G. R. Alexander Bestuzhev-Marlinsky by Lauren G. Leighton // Canadian Slavonic Papers 1977. Vol. 19, no. 1 (March). P. 100-101.

9 Shepard E. C. Alexander Bestuzhev-Marlinsky by Lauren G. Leighton // The Russian Review. 1976. Vol. 35, N 2 (April). P. 222-223.

10 Terras V. Alexander Bestuzhev-Marlinsky by Lauren G. Leighton // The Slavic and East European Journal. 1975. Vol. 19, N 3 (Autumn). P. 329-331.

${ }_{11}$ O’Mara P. K. F. Ryleev. Politicheskaia biografiia poeta dekabrista. Moscow, 1989.

12 Ibid. P.233.

${ }^{13}$ Leighton L. G. K. F. Ryleev: A Political Biography of the Decembrist Poet by Patrick O’Meara // The Russian Review. 1985. Vol. 44, N 3 (July). P. 301-302. 
L. Bagby took an entirely different course ${ }^{14}$. He consistently analyzes A. A. Bestuzhev's works alongside with his involvement in the secret society. However, addressing the period of the interregnum, in particular 1825 , he suddenly perceives the events in the context of carnival rituals ${ }^{15}$. Thus, he points out the bloody sacrifices, the destruction of social hierarchy and even the fact that the date of the revolt (December 14, 1825) coincided with the winter solstice, i.e. the time of pagan festivities. It should be pointed out that such interpretation doesn't in the least agree with real facts. With respect to this, the work by D. Gehrenbeck appears to be much more substantiated ${ }^{16}$. The scholar pursues an ambitious objective to separate political and aesthetical components of the activities of poets-Decembrists. In his thesis he highlights the main political images, typical of their poetry. However, we hold an opinion that in this case the poetry and the context, within which the literary views of the poets were taking shape, should be linked to politics rather than separated from it.

Thus, the provided historiographic review of the usage of literary devices by K. F. Ryleev and his closest associates demonstrates that the above-mentioned issue has been explored in the historical and philological studies. However, there hasn't been demonstrated an interdisciplinary approach. Historians reconstructed the political biographies of their protagonists, while philologists examined the literary influences they had fallen under and the key images of their works. As a result, the fusion of these two trends of research did not take place, not to mention the unsuccessful attempt by L. Bagby. Nevertheless, the abundant factual material, which urges the researches to analyze the events of the interregnum in the context of political allusions, has been accumulated.

The emergence of a "dictator", initiated by K. F. Ryleev, became the most representative of these allusions. This title gave rise to a heated debate fueled by the fact that S.P. Trubetskoi did not show up on Senate square on the fixed day. The information about the "dictator" can be found in the "Report of the Committee of Inquiry", the first published record of the revolt, which reflected the authorities' view on the events. In the "Report..." S.P. Trubetskoi is featured as an active participant in the revolt preparation. He was elected dictator - "a sole master"17. His absence on Senate square allegedly was one of the main reasons for the failure the revolt.

N.F. Lavrov was the first to put forward the hypothesis that S. P. Trubetskoi's authority as a "dictator" implied that he was in charge of the political aspect of the preparation and organization of the revolt, while the military commanders A. M. Bulatov and A. I. Iakubovich were allegedly expected to guarantee the military success of the venture. M. V.Nechkina described the article of N. F. Lavrov as an "attempt to rehabilitate the ill-starred dictator"18. According to M. V. Nechkina, in the period of early interregnum the Decembrists noble revolutionaries, being in the state of emergency, elected S. P. Trubetskoi dictator, in whom unlimited powers were vested. He worked out the plan of the revolt reflected in the Manifest to the Russian people. In other words, the historian believes that the position of a

14 Bagby L. Aleksandr Bestuzhev Marlinskii i russkii baironizm. St. Petersburg, 2001.

15 Ibid. P. 149.

16 Gehrenbeck D. L. Decembrist (Self-) Mythification. Disentangling the Political from the Aesthetic in the Works of Ryleev, Kiukhelbeker and Bestuzhev-Marlinskii. Doctoral dissertation. Providence, Rhode Island, 2000.

17 Vsepoddanneishii doklad vysochaishe uchrezhdennoi Sledstvennoi komissii ot 30 maia $1826 \mathrm{~g}$. // Vosstanie dekabristov: Materialy po istorii vosstaniia dekabristov. Vol. 17. Moscow, 1980. P. 49.

${ }^{18}$ Nechkina M. V. Dvizhenie dekabristov. Vol.2. Moscow, 1955. P. 223. 
dictator made him both a political and military leader of the secret society in the period of interregnum and revolt. Ia.A. Gordin breathed new life into the hypothesis of N. F. Lavrov and placed a special emphasis on the political functions of a dictator, putting the blame for the failure on his associates - Decembrists A. M. Bulatov and A. I. Iakubovich ${ }^{19}$.

V.P. Pavlova provides a number of new arguments in favor of N. F. Lavrov's view ${ }^{20}$. In particular, a letter of A. M. Bulatov to Grand Duke Mikhail Pavlovich, in which the former accentuated the significance of the political functions of a dictator. A.M. Bulatov cited the words of K. F. Ryleev that "S. P. Trubetskoi, a temporarily appointed dictator, would allegedly establish a Caretaker government which would appoint the members of the people's governing body" 21 . V.P. Pavlova comes up with another argument to confirm the idea that a dictator was not expected to command the troops on the square. In her article V.P. Pavlova claims that "in similar situation in October-November 1825, in the south, when the decision about an immediate action was made, P.I. Pestel appointed S. I. Muraviev-Apostol Commander in Chief taking over the general leadership"22.

According to E.M.Darevskaia, V.P. Pavlova "unfortunately was carried away by Ia.A. Gordin's 'innovation', having extended and intensified it in order to rehabilitate Trubetskoi" 23 . The works of Ia.A. Gordin and V.P. Pavlova drew attention to the question of the duties of A.M. Bulatov on December 14. N. G. Remizova also focuses on this topic in her article. Having analyzed different views on the hypothetical change of dictator on the eve of the venture, she arrives at a conclusion that "there was no valid evidence that the replacement of Trubetskoi with Bulatov had taken place"24. M. M. Safonov, on the contrary, insists that the replacement occurred, and it was A. M. Bulatov in whom the power to command the revolt was vested ${ }^{25}$.

Thus, the issue of the status and duties of a dictator have caused debate and given rise to two opposite standpoints: 1) It was S.P. Trubetskoi who was authorized to take command as elected "dictator" - military and political leader; 2) A. M. Bulatov as a deputy commander, who may have been appointed dictator at the last moment, was entitled to head the insurgents. It is also noteworthy that the very fact of S. P. Trubetskoi's election has never been questioned by the historians.

Usually, with respect to this issue a number of typical statements are taken into account. Only K. F. Ryleev, P.G. Kakhovskii, E. P. Obolenskii, A. A. Bestuzhev and S. P. Trubetskoi himself demonstrated relative awareness of the election. K. F. Ryleev during the investigation reported: "Being aware of the difference of opinion, which often occurs, I talked to Obolenskii and suggested proposing S.P. Trubetskoi for election having used the votes of Bestuzhev and Kakhovskii (in his favor). The next day I informed Obolenskii about this,

19 Gordin Ia. A. Miatezh reformatorov: 14 dekabria 1825 goda. Leningrad, 1989.

20 Pavlova V. P. Dekabrist S. P. Trubetskoi // S. P. Trubetskoi. Materialy o zhizni i revoliutsionnoi deiatel'nosti. T.1. Irkutsk, 1983. S.3-70.

21 Delo A. M. Bulatova // Vosstanie dekabristov: Materialy po istorii vosstaniia dekabristov. Vol.18. Moscow, 1984. P. 291.

22 Pavlova V.P. Dekabrist S. P. Trubetskoi. P. 43.

23 Darevskaia E. M. Zavershen li spor o S. P. Trubetskom? // Istoriia SSSR. 1990. N 5. P. 159.

24 Remizova N. G. Bulatov ili Trubetskoi? // Obshchestvennoe dvizhenie v Rossii v XIX — nachale XX v. Ivanovo, 1988. P. 18.

25 Safonov M. M. Zimnii dvorets v planakh vystupleniia 14 dekabria 1825 goda // Dekabristy. Aktual'nye problemy i novye podkhody. Moscow, 2008. P. 228-291. 
having added my own vote for Trubetskoi" ${ }^{26}$. E. P. Obolenskii mentioned both the election in the early interregnum period ${ }^{27}$ and the appointment of S. P. Trubetskoi ${ }^{28}$. P. G. Kakhovskii argued that it was K. F. Ryleev, who had appointed the dictator ${ }^{29}$. A. A. Bestuzhev claimed that he had given his vote for S. P. Trubetskoi during his conversation with K.F. Ryleev ${ }^{30}$. Thus, the only person who actually acknowledged taking part in the election was A. A. Bestuzhev.

Meanwhile, two thirds of 47 convicts, who had stayed in St. Petersburg in the interregnum period, did not mention the election at all, which means that they did not vote and probably knew nothing about it. Eight people claimed that they had known about of S.P.Trubetskoi's election, but for them it had been a fait accompli. Summing up all the above-mentioned evidence, it can be stated that the existing formula "S. P. Trubetskoi was elected dictator" should be overhauled in favor of a more accurate one "K. F. Ryleev by mutual arrangement with A. A. Bestuzhev and E. P. Obolenskii proclaimed S. P. Trubetskoi a dictator". Therefore, S. P. Trubetskoi's appointment was solely the initiative of K. F. Ryleev. We will also add that the materials of investigation do not contain any information about the election of assistant dictators or the chief of staff. In fact, nobody ever elected them.

The Decembrists themselves responded to the introduction of a new title in different ways. A. A. Bestuzhev, the closest friend of K. F. Ryleev, stated at the interrogation: "When Ryleev called him a dictator, I said it was a farce"31. A. A. Bestuzhev voted for S.P. Trubetskoi but did not approve of the title, which he probably considered too pompous. P.N. Svistunov, a member of the Southern Society, who stayed in St. Petersburg in December 1825, also called this title "inappropriate"32.

Giving evidence to the investigators, K. F. Ryleev pointed out that the introduction of the position of dictator had been caused by the need for undivided authority and a firm hand to rule the society. Meanwhile, the title, proposed by him, was an unusual one. The term "dictator" could have hardly been derived from the contemporary history. This word had never been used in the context of revolutionary or political events in Russia or countries of Europe. The only context where it could have been derived from was the ancient history. In the republic of Rome at the time of emergency two democratically elected consuls used to be replaced with a specifically appointed dictator entrusted with full authority.

As V.S.Parsamov pointed out ${ }^{33}$, some legends of the ancient times were often referred to in order to glorify the heroic deeds of the Russian soldiers in the Patriotic was of 1812. As a romantic poet, K. F. Ryleev knew about the method of allusions to historical subjects as the means of praising heroism and drew on it in his works. The usage of the title "dictator" was supposed to contribute to the glorification of the events in question.

${ }^{26}$ Delo K. F. Ryleeva // Vosstanie dekabristov: Materialy po istorii vosstaniia dekabristov. Vol. 1. Moscow; Leningrad, 1925. P. 160.

27 Delo kniazia E. P. Obolenskogo // Vosstanie dekabristov: Materialy po istorii vosstaniia dekabristov. Vol. 1. Moscow; Leningrad, 1925. P. 245.

28 Ibid. P. 235.

29 Delo P. G. Kakhovskogo // Vosstanie dekabristov: Materialy po istorii vosstaniia dekabristov. Vol. 1. Moscow; Leningrad, 1925. P.347.

30 Delo A. A. Bestuzheva // Vosstanie dekabristov: Materialy po istorii vosstaniia dekabristov. Vol. 1. Moscow; Leningrad, 1925. P. 443.

31 Ibid. P. 443.

32 Svistunov P.N. Sochineniia i pis'ma. Vol. 1. Irkutsk, 2002. P. 170.

33 Parsamov V.S. K genezisu politicheskogo diskursa dekabristov. Ideologema "narodnaia voina" // Dekabristy. Aktual'nye problemy i novye podkhody. Moscow, 2008. P. 159-194. 
Thus, it can be stated that K. F. Ryleev endued this term with a number of images loaned from the Roman literature, which were related to the figure and attributes of a leader at the time of emergency. Taking into consideration the background and the military rank of S. P. Trubetskoi, the title of "dictator" made his image genuine and complete. A combat officer who took part in the Patriotic war, a prince from the Gediminovichs' clan, a "dictator of the insurrection", a champion of the Constitution and representative government - all this could not but fascinate the officers, who had already taken part in the preparation for the revolt and whom K. F. Ryleev planned to engage in the venture later. This image was also supplemented with S.P. Trubetskoi's personal traits: composure, secretiveness and a touch of arrogance.

K. F. Ryleev appointed S. P. Trubetskoi dictator in order to use him as a symbol and to take advantage of his position and name. We can produce a number of facts to confirm this hypothesis. The name of S. P. Trubetskoi enabled K. F. Ryleev to promote his decisions. As P. G. Kakhovskii vividly described it, Ryleev "used to silence us in private conversations as well, passing his own ideas off as the will of the Dictator, who, I presume, could have been the figment of Ryleev's vanity"34. The name of S. P. Trubetskoi gave an opportunity to create illusions about the scale of the conspiracy and the support of the high-level institutions. The foremost aspect was that the name of S. P. Trubetskoi enabled K. F. Ryleev to change the admission rules.

The statements of the convicts clearly indicate that the members admitted in 1825 had been attracted to the society through their enthusiasm for the idea of constitution. However, Colonel A.M.Bulatov, admitted at the time of interregnum, was recruited in a different way: he was informed about the conspiracy headed by S. P. Trubetskoi (the dictator) and aimed at the introduction of the constitution. This process can be easily reconstructed from the investigation documents. K. F. Ryleev met with A.M.Bulatov on December 9 and told him about the society's plans of rising against the "tyrannical government and power" 35 and about the election of S.P. Trubetskoi. A fleeting encounter with the latter on December 12 was enough for A.M. Bulatov to believe that S. P. Trubetskoi wanted to ascend the throne and cherished hopes to "become an undisputed sovereign" ${ }^{36}$. Despite its unsuccessful outcome, the model of recruiting used by K. F. Ryleev is worth focusing on. It represents the following pattern: an encounter with an old friend, whom he had not seen for a while, account of the agenda, acquaintance with the "dictator", charging with some commissions. That is the reason why some Decembrists "were convinced and died in the firm belief that it was him (S. P. Trubetskoi $-M$. B.) who was entitled to head the troops"37.

However, the election of S.P. Trubetskoi by no means limited or lessened the leading role of K. F. Ryleev. It is interesting to mention that S.P. Trubetskoi himself accentuated this fact during the interrogation more than once. During the first questioning S. P. Trubetskoi stated that K. F. Ryleev and E. P. Obolenskii considered it possible to excite a revolt in St. Petersburg and that "they urgently needed S. P. Trubetskoi as his name could encourage the participants"38. Being questioned on December 23, S.P. Trubetskoi passed

\footnotetext{
34 Delo P.G. Kakhovskogo. P. 347.

35 Delo A. M. Bulatova. P. 291.

36 Ibid. P. 322.

37 Safonov M. M. Zimnii dvorets v planakh vystupleniia 14 dekabria 1825 goda. P. 257.

${ }^{38}$ Delo kniazia S.P. Trubetskogo. P. 6.
} 
the following words of K. F. Ryleev: "my name was essential for them and they knew I had been appointed the leader among them" ${ }^{39}$. Answering the questions on February 15, S. P. Trubetskoi gave an account of the events of December 12 and accentuated: "I intended pulling out of the society since the situation depressed me. I realized that the members needed only my name and nothing else" 40 . The above-mentioned quotes clearly indicate that S.P. Trubitskoi successively asserted that the dictator election plan had been worked out in order to take advantage of his big name and lure the participants into the revolt.

There is no doubt that the tendency to put the blame on K. F. Ryleev can be found in this statement. However, during the investigation "Ryleev put the blame"on Trubetskoi and the latter "tried to defend himself" 41 . Hence, it follows that S. P. Trubetskoi could have emphasized this story but could hardly have made it up. Thus, the above-mentioned quotes indicate that S.P. Trubetskoi clearly realized that K. F. Ryleev and the renewed Northern Society needed his name more than actual leadership on his part. S. P. Trubetskoi was destined to be the "banner" of the revolt rather than its head.

It should be also observed that in the course of preparation for the revolt K. F. Ryleev widely used the pronounced allusion to the history of ancient Rome and suggested honoring S.P. Trubestkoi with the title of dictator. Exploiting this title, he managed to push through some of his decisions, referring to the authority of a "dictator", and started recruiting new prospective insurgents. The presence of a "dictator" by no means prevented him from making independent decisions and orchestrating the revolt. Some of the Decembrists (A. A. Bestuzhev, P.N. Svistunov) were not impressed by the image of a "dictator", others, on the contrary, were agitated to such an extent that suspected S.P. Trubetskoi of harboring monarchist ambitions. Nevertheless, the above-mentioned analysis of the issue enables us to settle the dispute about the status and duties of a "dictator". To sum up, S.P. Trubetskoi by no means was meant to take the political and military command of the revolt.

Another obvious allusion was related to the regicide plans of the Decembrists. This issue is widely covered in the investigation files and the "Report..." In particular, it is stated that in the evening of December 13, K. F. Ryleev invited P. G. Kakhovskii to commit a regicide. On the day of the oath the latter was supposed to wear his Grenadier uniform, go to the palace and wait for the emperor ${ }^{42}$. However, he quickly turned down this proposal.

M.V.Nechkina more than once states that the Decembrists suggested putting off the decision about the future fate of the royal family until the Great Council. However, she repeats the story about the proposal by K. F. Ryleev, fully drawing on the information provided by the "Report..." 43 . Meanwhile, let us hope that someday in the future a scholar will make an attempt to analyze this work by a Soviet academician, applying the methods of metahistory. The idea of authorizing the Great Council to make the final decision emphasizes the "discreet charm" of the principle of revolutionary legitimacy as much as the materials of the investigation ignore it.

\footnotetext{
39 Ibid. P. 19.

40 Ibid. P. 58.

41 Safonov M. M. Zimnii dvorets v planakh vystupleniia 14 dekabria 1825 goda. P. 228.

42 Vsepoddanneishii doklad vysochaishe uchrezhdennoi Sledstvennoi komissii ot 30 maia $1826 \mathrm{~g}$.

43 Nechkina M. V. Dvizhenie dekabristov. Vol. 2. P. 241-244.
} P. 51. 
M.M. Safonov accurately collected and compared all the documents related to the prospective regicide attempt by P.G. Kakhovskii. The analysis of the above-mentioned documents confirmed that the episode in question had been misinterpreted in the past. The evidence given by K.F. Ryleev did not imply that P. G. Kakhovskii had declined this mission ${ }^{44}$. Meanwhile, the historian attributes the regicide plan itself to the revolt preparation crisis, which became obvious in the evening of December 13: there was a feeling of apathy, the hopes that certain regiments would join in were fading ${ }^{45}$.

V.S. Parsamov, examining the role of regicide in the political practice of the Decembrists, took note of their tendency to add some "Roman touch" to it ${ }^{46}$. The scholar explains this by their wish to avoid parallels with the execution of Louis XVI and the assassination of Paul I. N.D. Potapova supported the theory of V.S. Parsamov, having pointed out that the statements of P.G. Kakhovskii, G. S. Baten'kov and A. M. Bulatov contained clear allusions to the biography of Brutus ${ }^{47}$. It is unlikely that the above-mentioned parallels could have accounted for these references to Roman history. The intellectuals of the early XIX century, well acquainted with the ancient tradition, undoubtedly associated the figure of a Russian tsar with that of a Roman emperor ${ }^{48}$. Therefore, an attempt of regicide was inevitably associated with the issue of tyrant-fighting. One can challenge the position of V.S.Parsamov using his own argument: in chapter X of A.S. Pushkin's Eugene Onegin I. D. Iakushkin's prospective attempt on the life of Alexander I (in literature often referred to as the duel regicide scenario $)^{49}$ is placed in the tyrant-fighting context ${ }^{50}$.

The sources confirm this observation. At the interrogation, P. G. Kakhovskii insisted that "Ryleev, seeing my ardent love for my country and for freedom, as well as my passionate and resolute character, tried to lure me into becoming a weapon in his hands... I will not dwell on his words, but he used to cite Brutus and Sand as examples" ${ }^{51}$. The eloquence of K. F. Ryleev proved to be convincing. The very next day after this conversation P. G. Kakhovskii in the same manner tried to incite the naval cadets to commit regicide. V. A. Divov gave an account of this scene: "After he had left, a young man in a blue frockcoat came in and went with Arbuzov to another room. When he came back, he asked if any of us needed a dagger... Then he kissed each of us and said: "Goodbye, gentlemen, see you on the square" 52 . In this episode two symbols related to tyrant-fighting can be clearly distinguished: a dagger as a weapon of Brutus, and a kiss as a form of blessing. It should be taken into consideration that the people, who took part in it, did not know each other. That is why we can hardly agree with Ia.A. Gordin who wrote about the agitated state of

${ }_{44}$ Safonov M. M. Zimnii dvorets v planakh vystupleniia 14 dekabria 1825 goda. P. 252.

45 Ibid. P. 256

46 Parsamov V.S. Dekabristy i frantsuzskii liberalizm. Moscow, 2001. P. 165.

47 Potapova N. Tribuny syrykh kazematov. Politika i diskursivnye strategii v dele dekabristov. St. Petersburg, 2017. P.321.

${ }^{48}$ Bowersock G. W. The Roman Emperor as Russian Tsar: Tacitus and Pushkin // Proceedings of the American Philosophical Society. 1999. Vol. 143, N 1 (March). P. 130-147.

49 Odesskii M. P., Fel'dman D. M. Poetika terrora i novaia administrativnaia mental'nost': ocherki istorii formirovaniia. Moscow, 1997. P. 109-112.

50 "Melancholy Iakushkin, it seemed, silently bared a regicidal dagger".

51 Delo P. G. Kakhovskogo. P. 373.

52 Delo V. A. Divova // Vosstanie dekabristov: Materialy po istorii vosstaniia dekabristov. Vol. 14. Moscow, 1976. P. 295-296. 
P.G. Kakhovskii at that moment ${ }^{53}$. What we observe here is rather a cunning tactics with the purpose of luring the participants into action.

The evidence given by A. M. Bulatov also deserves attention: "Calmly taking leave of my brother Alexander, I had the misfortune to boast that if I took action, new Brutuses and Riegos would appear in our country" ${ }^{34}$. This is how A. M. Bulatov understood his mission on the eve of the revolt. On December 6, he knew nothing about the secret society, but on December 9, K. F. Ryleev tried to persuade him to "eliminate the tyrannical power of the tsars unfairly snatched away from the peoples" 55 . The definitions "tyrannical" and the "power unfairly snatched away from the peoples" represent allusions to the history of ancient Rome.

Thus, it can be stated that K. F. Ryleev in his narrative about the revolt and regicide used to appeal to the images from ancient Roman history. The allusion to the assassination of Julius Caesar and the association of a potential murderer with Brutus were important rhetorical methods of persuasion and achievement of political goals. The antipodal situation with A. I. Iakubovich, who was eager to kill Alexander I so as to revenge himself for the ruined military career and deportation to Caucasus, contributes to this conclusion. According to Ia.A.Gordin, A.I. Iakubovich personified a "romantic hero" drawn "into the sphere of practical politics" ${ }^{36}$. Despite all his agitation and obsession with regicide, K. F. Ryleev did his best to hold him back from this act, and even after the death of Alexander I did not urge him to make an attempt on the life of Nicholas. The point is that A. I. Iakubovich was guided by personal reasons, while K. F. Ryleev was orchestrating a striking and well-defined political scenario - assassination of a tyrant who had encroached upon the freedom of the people.

The setting for the revolt - Senate square - is also symbolic. M. V. Nechkina cultivated the stereotype that the Decembrists wanted "to keep the troops and the Senate from taking the oath" ${ }^{\prime 5}$. This means that they had to act straight after the signing of the accession Manifest and before the oath of the Senate members. Therefore, having received the news about the date of the oath, they scheduled the revolt for that day. According to M.V.Nechkina, the first and foremost objective of the Decembrists was to stop the senators from pledging the oath. However, Iakov Rostovtsev - a traitor who happened to be in the ranks of the conspirators - reported about their plans to Nicholas. The latter made arrangements to administer the oath very early, at seven oclock in the morning ${ }^{58}$. Following this logic, the choice of venue was obviously defined by geography.

However, the scenario proposed by M. V. Nechkina contains some conflicting data. It would have been impossible to stop the Senate from pledging the oath by force of the soldiers who had refused to pledge it. According to the traditional order, the members of the state institutions of high rank - the State Council and the Senate - were the first to take the oath, and only after that the guards and other troops were expected to take part in the ceremony. Obviously, none of the guards could have refused to take the oath by the moment when the Senate members were doing it. It is noteworthy that even the "Report..."

53 Gordin Ia. A. Miatezh reformatorov: 14 dekabria 1825 goda. P. 66.

${ }^{54}$ Delo A. M. Bulatova. P. 299.

55 Ibid. P. 291.

56 Gordin Ia. A. Miatezh reformatorov.

57 Nechkina M. V. Dvizhenie dekabristov. Vol. 2. P. 247.

${ }^{58}$ Ibid. P. 264. 
(the document which outlined the official concept of Nicholas's government), to which M.V.Nechkina often drew on substituting negative assessments for positive, did not touch upon this issue ${ }^{59}$. That is why the question remains open: why was Senate square chosen as a venue for the revolt? Practical reasons alone definitely cannot account for this.

We will also note that the revolt scenario, which included the stand of the guards on one of the central squares, in many aspects was modeled on the revolution in Brazil. The report of the Russian ambassador in Brazil, F. V.Teil'-fan-Serokerken, contains the description of the events strikingly similar to those which took place at an early stage of St. Petersburg revolt ${ }^{60}$. This similarity was noted by A. B. Sheshin: "It is interesting to highlight the similarity of the revolutionary events of the 1820s on different continents and the potential victory of the revolt of December 14, in Petersburg, the victory, which was achieved by the Brazilian insurgents on February 14 (26) 1821"61.

Senate square looked differently at the time: St. Isaac's Cathedral was still under construction, in the place of the present Senate building there was the mansion of A. P. Bestuzhev-Riumin, where the above-mentioned institution was quartered. However, the Bronze Horseman, a monument to the founder of the Russian empire, towered over the square in the same manner as it does now. A few years after the Decembrist revolt, A.S. Pushkin would write one of the most complicated and mystical poems about this monument - the Bronze Horseman. In this context the study of Andrei Belyi (B. N. Bugaev) deserves attention: having examined the rhythmical structure of the poem by A.S. Pushkin "The Bronze Horseman", he drew a conclusion that the text contains a codified version of the suppression of the Decembrist revolt by Nicholas ${ }^{62}$. M. Banerjee in her article "The Bronze Horseman: an Agonistic Vision" supports this theory ${ }^{63}$.

G.V.Vernadsky drew a number of parallels between the events of the poem and the revolt. One of them is particularly remarkable: among the poet's sketches there was one featuring the monument by Falcone but without a horseman. According to the historian, this image "reflects Pushkin's vision of what would become of Russia in the case of the success of the Decembrists" 64 . In short, it should be taken into consideration that the intellectuals of the XIX century associated the monument to Peter I with autocracy, the mighty state machine and the Empire in general. In the intellectual milieu the image of the Bronze Horseman replaced the one introduced by Radishchev - "chudishche oblo, ozorno, ogromno, stozevmo I laiai" ${ }^{2}$.

59 For more details about the influence of the "Report" on the concept of M. V.Nechkina see.: Belousov M. S. "Predatel'stvo" S. P. Trubetskogo: pro and contra // Vestnik Sankt-Peterburgskogo universiteta. Seriia 2. Istoriia. 2014. Iss. 4. P. 15-30.

60 Poslannik v Rio-de-Zhaneiro F. V.Teil'-fan-Serokerken stats-sekretariu K. V. Nessel'rode ot 19 fevralia (3 marta) 1821 g. // Vneshniaia politika Rossii XIX i nachala XX veka: Dokumenty rossiiskogo ministerstva inostrannykh del. Seriia II. Moscow, 1961. Vol. IV (XII).

${ }_{61}$ Sheshin A.B. K analizu sobytii vosstaniia 14 dekabria 1825 g. // Dekabristy. Aktual'nye problemy i novye podkhody. Moscow, 2008. P.292-337.

${ }_{62}$ Andrei Belyi. Ritm kak dialektika i "Mednyi vsadnik". Moscow, 1929.

${ }^{63}$ Banerjee M. Pushkin's "The Bronze Horseman": an Agonistic Vision // Modern Language Studies. 1978. Vol. 8, N 2 (Spring). P. 47-64.

${ }^{64}$ Vernadsky G. V. Pushkin and the Decembrists // Centennial essays for Pushkin. Cambridge, 1937. P. 73. For the more detailed analysis of the views of this Russian-American scholar on the history of the Decembrist movement see: Dvornichenko A. Yu., Belousov M. S. Dvizhenie dekabristov v tvorchestve Georgiia Vernadskogo // Vestnik Sankt-Peterburgskogo universiteta. Istoriia. 2017. Vol. 62, iss. 2. P. 358-374.

65 "The beast is enormous, disgusting, a-hundred-maws and barking" - an image commonly associated with autocracy. 
R. Wortman, an American historian, emphasized: "Although few representatives of the gentry had joined the Decembrists, their revolt for the first time since 1730 openly refuted the myth of Peter I, being the driving force of the social progress"66. Developing the idea of the American historian, it is appropriate to interpret the Decembrist revolt as a revolt against the autocracy, which came into being due to Peter I and was embodied in the Bronze Horseman, a monument, which dominates Senate square. This hypothesis provides an explanation for the choice of venue.

The observations of M.M. Safonov, who was the first to notice certain logic in the events of November 27, 1825, suggest another explanation. In fact, the law of succession to the throne in Russia was quite distinct: 1) a monarch dies 2) his heir drafts an accession manifest 3) the pledge of allegiance takes place in accordance with the text of the oath enclosed to the manifest. Nicholas, having received the news about the death of his older brother, immediately pledged his oath to Constantine. According to M. M.Safonov, by doing this Nicholas broke the "traditional law, having pledged the oath without the publication of the accession manifest of a new monarch" ${ }^{37}$, hence having sparked a political crisis of interregnum. However, having made this important observation, the historian overlooked one detail. Nicholas had to impart legitimacy to his actions - the mere oath, administered with the breach of tradition and without the order of the Senate, would have seemed quite dubious.

That is why it was not the Grand Duke, but the Senate that initiated the oath. On November 27, the Senate published a Manifest which contained the news about the death of Alexander I and the order to pledge the oath to his heir Constantine ${ }^{68}$. The text of the oath, first delivered by Nicholas, was enclosed with the Manifest. Consequently, it was the Senate which triggered a legal crisis of the interregnum, and whose order resulted in a dynastic deadlock. This situation actually mirrored the events of 1682 and 1730, when the supreme state body had appointed the successor of the late tsar. Moreover, this order imparted legitimacy only to the decrees issued by the Senate. Since Constantine had not ascended the throne by that moment, the supreme legal authority in the period of interregnum was entirely in the hands of the Senate. This particular situation is believed to have predetermined the Decembrists' attitude to the Senate in general.

Undoubtedly, the leaders of the secret society were aware of the above-mentioned legal crisis. Thus, G.S. Baten'kov stated at the questioning: "Once discussing with Trubetskoi the procedure of how the Senate had announced the accession of his Majesty the Cesarevich (Constantine - M. B.) I thoughtlessly remarked that it would not take a lot of effort to excite a revolution in our country: once the Senate made an announcement and published the decrees" 69 . In this statement Baten'kov actually comments on the events which took place on November 27.

S.P. Trubetskoi in his written statement reported: "there were some rumors that the guards would be allegedly taken out of the city to administer the oath; another rumor

66 Wortman R. Stsenarii vlasti. Mify i tseremonii russkoi monarkhii. Vol. 1. Moscow, 2006. P. 348.

67 Safonov M. M. Mezhdutsarstvie // Istoricheskii opyt russkogo naroda i sovremennost'. Materialy k dokladam 19-22 iiunia 1995 g. St. Petersburg, 1995. P. 168.

68 Zakon № 30592 ot 27 noiabria 1825 goda “O konchine gosudaria imperatora Aleksandra Pavlovicha i priniatii prisiagi na vernost' poddanstva Gosudariu Imperatoru Konstantinu Pavlovichu” // Polnoe sobranie zakonov Rossiiskoi imperii. Vol. 40. St. Petersburg, 1830. P. 616.

${ }^{69}$ Delo G. S. Baten'kova // Vosstanie dekabristov: Materialy po istorii vosstaniia dekabristov. Vol. 14. Moscow, 1976. P. 85. 
claimed that the troops would be informed about the accession to the throne of his Majesty the Emperor Nikolai Pavlovich not by the Manifest, but by the written order (italics M. B.)"70. In this statement S. P. Trubetskoi referred to his letter to S. I. Muraviev-Apostol, in which the former made disguised hints at the future events: with respect to the "intention of taking the troops out of the city to administer the oath" S. P. Trubetskoi hinted at the revolt and the consequent plan of taking the regiments, which had refused to pledge the oath, out of the city. The second part of the sentence can be interpreted in the following way: On December 13, when Trubetskoi was writing the letter, he believed that the next move in the chain of events would be the order of the Senate to pledge the oath to Nicholas - not the publication of the accession manifest by Nicholas.

This interpretation gives an opportunity to reconsider the events of December 14. Apparently, the Decembrists intended to persuade the soldiers to keep their oath to Constantine not so as to jeopardize the Manifest of Nicholas's accession to the throne, but so as to challenge another order of the Senate. This means that from the legal point of view, they opposed not the new successor, Grand Duke Nikolai Pavlovich, but the decision of the Senate. This explains the excessive importance the Decembrists attached to the Senate in view of the forthcoming events. Indeed, it was the Senate, whose members were meant to publish the Manifest written by S. P. Trubetskoi on the sheet of paper from his notebook, where he copied the text of the Constitution, drafted by N. M. Muraviev ${ }^{71}$.

Therefore, K. F. Ryleev's objective was not to arrest certain senators and force them into issuing a manifest. On the contrary, the stand on the square was conceived as an armed public demonstration (modeled on the Brazil revolution) held in front of the building of the state body authorized to make decisions about the further fortune of the dynasty and the political order of Russia. Needless to say, any public demonstration in the first place appeals to the spectators rather than to the officials of the relevant institution. That is why, it is no coincidence that $\mathrm{K}$. F. Ryleev continued the implementation of his plan with triple force, having received the news that the senators had taken the oath and were about to depart.

One more location, namely the island of Leon, should be considered in the context of the revolt geography. This small island, located by the southern seaboard of Spain, is mentioned more than once in the materials of the investigation and the statements of the Decembrists. K. F. Ryleev claimed: "I indeed referred to Kronstadt as to the island of Leon twice"72. According to N. A. Bestuzhev, K. F. Ryleev firmly believed that "in the case of failure Kronstadt, being a secure and remote place, could serve the same purpose for the Russians as Leon did for the Spaniards"73. G. S. Baten'kov mentioned that N. A. Bestuzhev had been trying to talk K. F. Ryleev out of this idea, accentuating that "(Bestuzhev - M. B.) argued that, in Ryleev's opinion, Kronstadt is our Leon — but it is the place where cards and billiards are the only things that matter" 74 .

Both the Decembrists and the investigators understood this allusion quite well, and the topic of the island of Leon did not give rise to any additional questions. Both parties

70 Delo kniazia S. P. Trubetskogo. P. 42.

71 Safonov M. M. Lozh' i pravda o 14 dekabria 1825 goda // Nikolaiu Alekseevichu Troitskomu k iubileiu. Saratov, 2011. P. 150.

72 Delo K. F. Ryleeva. P. 183

${ }^{73}$ Delo N. A. Bestuzheva // Vosstanie dekabristov: Materialy po istorii vosstaniia dekabristov. Vol. 2. Moscow; Leningrad, 1926. P. 73.

74 Delo G.S. Baten'kova. P. 84. 
knew what they were talking about. Presumably, the above-mentioned statements touched upon the events of the first Spanish revolution, when the country turned out to be both occupied by the army of Napoleon and devoid of the ruler (as the king's family had been sent off to Bayonne). Under those circumstances, the Central Junta, which delegated the power to the Regency, emerged. The Regency established the emergency Cortes which started exercising its functions on September 24, 1810, on the island of Leon. Having worked for 4 years, the Cortes adopted the most liberal of all contemporary Constitutions, which became the symbol of struggle against absolutism.

It can be assumed that K. F. Ryleev, talking about Kronstadt being a Russian equivalent of the island of Leon, implied the possibility of retiring into this place in the case of failure to convene the Great Council and to carry out all the necessary reforms. Meanwhile, it is worthy of note that, according to M. Artola Gallego, the Regency had not fully realized its plan with regard to the election of the Cortes members. As a result, the first elected members, upon arriving in Cadiz, made a decision to recruit new members from the citizens of other provinces, who stayed in Cadiz at the time. T. A. Alekseeva agreed with this observation and pointed out that initially the Cortes had mostly consisted of the so-called deputy members ${ }^{75}$. Any citizen of the region who stayed in Cadiz at the time of the Cortes session had the right to stand for the election as a deputy member from a certain area.

Moreover, P. Gomez Aparicio emphasizes the fact, that "due to the proximity to Gibraltar, British Masonic lodges had their branches there"76 and the political life was in full swing. Thus, it can be concluded that K. F. Ryleev initially speculated that the defeated rebels could allegedly settle in Kronstadt and form the Great Council from the representatives of different provinces. This hypothesis is confirmed by the warning of N. A. Bestuzhev, who was well aware of what was going on in Kronstadt, and claimed that "the only thing they do there is to indulge in cards and billiards"77. This warning implies that K. F. Ryleev's plan was doomed to failure as the military men quartered in Kronstadt were not inclined to engage in political activities.

Summing up, let us outline the main points of this article. Many political allusions can be found in the history of interregnum. Their usage was largely inspired by K. F. Ryleev, the mastermind of the St. Petersburg revolt. It was K. F. Ryleev who proposed a title of the dictator for S.P. Trubestkoi. The underlying motive behind this initiative was to take advantage of the latter's big name in order to promote particular decisions and recruit new members. It was K. F. Ryleev who referred to the name of Brutus in the context of the regicide plan in order to lure the potential executors into committing it. It was K. F. Ryleev's idea to take the rebels to Senate square to take a stand there.

Thus, appealing to the supreme state body, the leader of the Northern Society, was actually eager to implement the model of the Brazil revolution - an armed public demonstration. The choice of venue (Senate square) was also associated with the Senate's status and its role in the crisis of interregnum. The allusion to Leon Island indicates that one of the prospective scenarios in the case of defeat was to retire to Kronstadt and to form the Great Council there. To put it briefly, the analysis of the political allusions provides

\footnotetext{
75 Alekseeva T. A. Zakonodatel'stvo ispanskoi revoliutsii 1808-1814. St. Petersburd, 1996. P. 27.

${ }^{76}$ Gomez Aparicio P. Historia del periodismo espanol, Vol. II. Madrid, 1967.

77 Delo G. S. Baten'kova. P. 84.
} 
the opportunity to modify the existing entrenched views on the plans of the leader of the Northern Society on the eve of St. Petersburg rebellion.

\section{References}

Alekseeva T. A. Zakonodatel'stvo ispanskoi revoliutsii 1808-1814. St. Petersburg, Sankt-Petersburg university Press, 1996, 144 p. (In Russian)

Andrei Belyi. Ritm kak dialektika i "Mednyi vsadnik". Moscow, "Federatsiia" Publ., 1929, 280 p. (In Russian)

Artola Gallego M. Antiguo regimen y revolucion liberal. Barcelona, Ariel, 1978, 318 p.

Barratt G. R. Alexander Bestuzhev-Marlinsky by Lauren G.Leighton. Canadian Slavonic Papers. 1977, vol. 19, no. 1 (March), pp. 100-101.

Bagby L. Aleksandr Bestuzhev Marlinskii i russkii baironizm. St. Petersburg, Akademicheskii proekt Publ., 2001, 368 p. (In Russian)

Belousov M. S. The "treason" of S. P. Trubetskoy: pro et contra. Vestnik of Saint Petersburg University. History, 2014, vol. 4, pp. 15-30. (In Russian)

Bowersock G. W. The Roman Emperor as Russian Tsar: Tacitus and Pushkin. Proceedings of the American Philosophical Society. 1999, vol. 143, no. 1 (March.), pp. 130-147.

Banerjee M. Pushkin's “The Bronze Horseman”: An Agonistic Vision. Modern Language Studies. 1978, vol. 8, no. 2 (Spring), pp. 47-64

Gehrenbeck D. L. Decembrist (Self-) Mythification. Disentangling the Political from the Aesthetic in the Works of Ryleev, KiukheFbeker and Bestuzhev-Marlinskii. Doctoral dissertation. Providence, Rhode Island, 2000. 343 p.

Gomez Aparicio P. Historia del periodismo espanol. Vol. II. Madrid, Editora Nacional, 1967, 735 p.

Gordin Ia. A. Miatezh reformatorov: 14 dekabria 1825 goda. Leningrad, Lenizdat Publ., 1989, 400 p. (In Russian)

Darevskaia E. M. Zavershen li spor o S. P. Trubetskom? Istoriia SSSR, 1990, no. 5, pp. 151-160. (In Russian)

Dvornichenko A. Yu. Smuta as a Factor of Russian History. Vestnik of Saint Petersburg University. History, 2018, vol. 63, iss. 3. (in print) (In Russian)

Dvornichenko A. Yu., Belousov M. S. Decembrist movement in the creativity of George Vernadsky. Vestnik of Saint Petersburg University. History, 2017, vol. 62, iss. 2, pp. 358-374. (In Russian)

Leighton L. G. Alexander Bestuzhev-Marlinsky. Boston, Twayne, 1975, 161 p.

Leighton L. G. K. F. Ryleev: A Political Biography of the Decembrist Poet by Patrick O'Meara. The Russian Review. 1985, vol. 44, no. 3 (July), pp. 301-302.

Maslov V.I. Literaturnaia deiatel'nost' K.F.Ryleeva. Kiev, Imperatorskiy universitet Sviatogo Vladimira Aktsionernogo obshchestva pechati i izdatel'skogo dela N. T. Korchak-Novitskogo Press, 1912, 144 p. (In Russian)

Mazour A.G. First Russian revolution 1825. The Decembrist movement. Its origins, development and significance. Stanford, California, Stanford University Press, 1937, 342 p.

Nechkina M. V. Dvizhenie dekabristov. Vol. I. Moscow, Nauka Publ., 1955, 483 p. (In Russian)

Nechkina M. V. Dvizhenie dekabristov. Vol. II. Moscow, Nauka Publ., 1955, 506 p. (In Russian)

Odesskii M.P., Fel'dman D.M. Poetika terrora $i$ novaia administrativnaia mental'nost': ocherki istorii formirovaniia. Moscow, RGGU Press, 1997, 204 p. (In Russian)

O’Mara P. K. F. Ryleev. Politicheskaia biografiia poeta dekabrista. Moscow, Progress Publ., 1989, 336 p. (In Russian)

Pavlova V.P. Dekabrist S.P.Trubetskoi. S. P. Trubetskoi. Materialy o zhizni i revoliutsionnoi deiatelnosti. Vol. 1. Irkutsk, East Siberian book publishing house, 1983, pp. 3-70. (In Russian)

Parsamov V. S. Dekabristy i frantsuzskii liberalizm. Moscow, Polimed Publ., 2001, 240 p. (In Russian)

Parsamov V.S. K genezisu politicheskogo diskursa dekabristov. Ideologema "narodnaia voina". Dekabristy. Aktual'nye problemy i novye podkhody. Moscow, 2008, pp. 159-194. (In Russian)

Potapova N. Tribuny syrykh kazematov. Politika i diskursivnye strategii v dele dekabristov. St. Petersburg, European University Press, 2017, 416 p. (In Russian)

Presniakov A. Motivy real'noi politiki v dvizhenii dekabristov. Bunt dekabristov. Leningrad, Byloe Publ., 1926, pp. 29-56. (In Russian)

Remizova N. G. Bulatov ili Trubetskoi? Obshchestvennoe dvizhenie v Rossii v XIX - nachale XX v. Ivanovo, 1988, pp. 3-27. (In Russian)

Safonov M.M. Zimnii dvorets v planakh vystupleniia 14 dekabria 1825 goda. Dekabristy. Aktualnye problemy i novye podkhody. Moscow, 2008, pp. 228-291. (In Russian) 
Safonov M. M. Lozh' i pravda o 14 dekabria 1825 goda. Nikolaiu Alekseevichu Troitskomu $-k$ iubileiu. Saratov, 2011, pp. 149-171. (In Russian)

Safonov M. M. Mezhdutsarstvie. Istoricheskii opyt russkogo naroda i sovremennost'. Materialy $k$ dokladam 19-22 iiunia 1995 g. St. Petersburg, 1995, pp. 166-181. (In Russian)

Sheshin A.B. K analizu sobytii vosstaniia 14 dekabria 1825 g. Dekabristy. Aktual'nye problemy i novye podkhody. Moscow, 2008, pp. 292-337. (In Russian)

Shepard E. C. Alexander Bestuzhev-Marlinsky by Lauren G. Leighton. The Russian Review. 1976, vol. 35, no. 2 (April), pp. 222-223.

Terras V. Alexander Bestuzhev-Marlinsky by Lauren G.Leighton. The Slavic and East European Journal. 1975, vol. 19, no. 3 (Autumn), pp. 329-331.

Tseitlin A. G. Tvorchestvo Ryleeva. Moscow, AN USSR Publ., 1955, 303 p. (In Russian)

Vernadsky G. V. Pushkin and the Decembrists. Centennial essays for Pushkin. Cambridge: Harvard University Press, 1937, pp. 45-76.

Wortman R. Stsenarii vlasti. Mify i tseremonii russkoi monarkhii. Vol.1. Moscow, OGI Publ., 2002, 604 p. (In Russian)

Received: 14.12.2017

Accepted: 30.03 .2018 